\title{
KEAHLIAN KHUSUS SEORANG TENAGA PENDIDIK
}

\author{
Mita Lestari \\ Email: 2010111220026@mhs.ulm.ac.id \\ Program Studi Pendidikan Sejarah Fakultas Keguruan dan Ilmu Pendidikan \\ Universitas Lambung Mangkurat \\ Banjarmasin
}

\begin{abstract}
Abstrak
Profesi merupakan suatu pekerjaan yang dilakukan oleh seorang ahli melalui berbagai pelatihan khusus dan persyaratan khusus. Profesi guru merupakan profesi yang tentunya sangat menentukan bagaimana masa depan bangsa ini. Jika seandainya guru tidak menguasai bahan pembelajaran, strategi pembelajaran serta mendorong siswa belajar untuk mencapai prestasi yang tinggi maka, segala upaya peningkatan kualitas pendidikan tidak akan mencapai hasil yang maksimal. Kualitas pendidikan sangat ditentukan oleh berbagai faktor, namun yang paling utama dan sangat dominan adalah kualitas professional seorang guru. Guru yang profesional minimal memiliki komitmen kepada peserta didik dan proses belajarnya, menguasai secara mendalam bahan pelajaran yang akan diajarkannya, serta cara penyampaiannya kepada siswa, bertanggung jawab memantau hasil belajar siswa melalui berbagai teknik evaluasi, mampu berpikir secara sistematis tentang apa yang dilakukan, mengadakan refleksi dan koreksi, belajar dari pengalaman dan memperhitungkan dampaknya pada proses belajar mengajar, dan seyogyanya merupakan bagian dari masyrakat belajar dalam lingkungan profesinya, sehingga menjadi interaksi yang luas dan profesional.
\end{abstract}

\section{PENDAHULUAN}

Profesi secara etimologi berasal dari kata profession (inggris) yang berasal dari bahasa Latin profesus yang berarti "mampu atau ahli dalam suatu bentuk pekerjaan". Profesi dapat diartikan sebagai suatu pekerjaan atau jabatan yang menuntut keahlian, yang didapat melalui pendidikan dan latihan tertentu, menurut persyaratan khusus memiliki tanggung jawab dan kode etik tertentu. Pekerjaan yang bersifar profesional berbeda dengan pekerjaan lainnya karena suatu profesi memerlukan kemampuan dan keahlian khusus dalam melaksanakan profesinya. Profesi juga diartikan sebagai suatu jabatan atau pekerjaan tertentu yang mensyaratkan pengetahuan dan keterampilan khusus yang diperoleh dari pendidikan akademis yang intensif. Jadi profesi adalah suatu pekerjaan atau jabatan yang 
menuntut keahlian tertentu. Artinya suatu pekerjaan atau jabatan yang disebut profesi tidak dapat dipegang oleh sembarang orang, tetapi memerlukan persiapan melalui pendidikan dan pelatihan secara khusus (Musriadi, 2016: 27-30).

Dalam bidang pekerjaan, profesi berarti pengakuan atau pernyataan tentang pekerjaan atau bidang pengabdian yang dipilih. Orang yang menyatakan profesinya sebagai guru, sebenarnya ia menyatakan bahwa pekerjaan yang dipilihnya adalah sebagai pendidik. Dilihat dari arti bahasa, guru sebagai pekerjaan mengandung makna kegiatan untuk mencari nafkah, karenanya, seorang guru akan menggantungkan hidupnya pada pendidikan (Nurjan, 2015: 1).

Profesi pada hakikatnya adalah suatu pernyatan atau suatu janji terbuka yang menyatakan bahwa seseorang itu mengabdikan dirinya pada suatu jabatan atau pelayanan karena orang tersebut merasa terpanggil untuk menjabat pekerjaan itu. Istilah profesi merupakan simbol dari suatu pekerjaan itu sendiri, profesi mengajar adalah suatu jabatan yang mempunyai kekhususan. Kekhususan itu merupakan kelengkapan mengajar atau keterampilan yang menggambarkan bahwa seseorang melakukan tugas mengajar, yaitu membimbing manusia (Musriadi, 2016: 30).

Guru yang diartikan sebagai tenaga professional dapat ditemukan dalam fenomena pendidikan Islam pada masa kemajuan dan modern pada periode ini, "Guru" menjadi sebuah profesi yang dapat diartikan usaha mencari penghasilan (nafkah). Dalam konteks ini guru bukan hanya mengemban amanat pendidikan, melainkan juga orang yang menyediakan dirinya sebagai tenaga professional yang bersedia menerima bayaran untuk menunjang tugasnya sebagai guru dan menafkahi keluarganya (Sidiq, 2018: 2).

Bedasarkan UU RI No.14 tahun 2005 tentang Guru dan Dosen Pasal 1, Guru adalah pendidik profesional dengan tugas utama mendidik, mengajar, membimbing, mengarahkan, melatih, menilai, dan mengevaluasi peserta didik pada pendidikan anak usia dini jalur pendidikan formal, pendidikan dasar, dan pendidikan menengah. Dosen adalah pendidik profesional dan ilmuan dengan tugas utama mentransformasikan, mengembangkan, dan menyebarluaskan ilmu pengetahuan, teknologi, dan seni melalui pendidikan, penelitian, dan pengabdian kepada masyarakat.

Menurut Noor Jamaluddin (1978: 1) Guru adalah pendidik, yaitu orang dewasa yang bertanggung jawab memberi bimbingan atau bantuan kepada anak didik dalam perkembangan jasmani dan rohaninya agar mencapai kedewasaannya, mampu berdiri sendiri dapat melaksanakan tugasnya sebagai makhluk Allah khalifah di muka bumi, sebagai makhluk sosial dan individu yang sanggup berdiri sendiri.

\section{PERAN GURU SEBAGAI SEBUAH PROFESI}

Menurut buku yang saya baca, disana tertulis sebuah kutipan yang menjelaskan tentang bagaimana tugas seseorang dalam melaksanakan profesinya yaitu, "Profesi dapat diartikan sebagai suatu pekerjaan atau jabatan yang menuntut keahlian, yang didapat 
melalui pendidikan dan latihan tertentu, menurut persyaratan khusus memiliki tanggung jawab dan kode etik tertentu. Pekerjaan yang bersifat profesional berbeda dengan pekerjaan lainnya karena suatu profesi memerlukan kemampuan dan keahlian khusus dalam melaksanakan profesinya. Profesi juga diartikan sebagai suatu jabatan atau pekerjaan tertentu yang mensyaratkan pengetahuan dan keterampilan khusus yang diperoleh dari pendidikan akademis yang intensif. Jadi profesi adalah suatu pekerjaan atau jabatan yang menuntut keahlian tertentu. Artinya suatu pekerjaan atau jabatan yang disebut profesi tidak dapat dipegang oleh sembarang orang, tetapi memerlukan persiapan melalui pendidikan dan pelatihan secara khusus." (Musriadi, 2016: 27-30).

Lalu dijabarkan dengan, "Profesi pada hakikatnya adalah suatu pernyatan atau suatu janji terbuka yang menyatakan bahwa seseorang itu mengabdikan dirinya pada suatu jabatan atau pelayanan karena orang tersebut merasa terpanggil untuk menjabat pekerjaan itu. Istilah profesi merupakan simbol dari suatu pekerjaan itu sendiri, profesi mengajar adalah suatu jabatan yang mempunyai kekhususan. Kekhususan itu merupakan kelengkapan mengajar atau keterampilan yang menggambarkan bahwa seseorang melakukan tugas mengajar, yaitu membimbing manusia." (Musriadi, 2016: 30).

Seorang guru dapat digolongkan serta di klarifikasikan sebagai profesi sesuai dengan kriteria diatas. Karena seorang guru telah melalui hari yang panjang dengan cara mempelajari bagaimana cara mendidik dan mampu menguasai pelajaran yang akan diajarkan. Seorang guru bahkan mampu membuat sebuah silabus kegiatan Selama belajarmengajar secara sistematis dan teratur. Mereka juga mempelajari bagaimana cara menarik perhatian para murid serta membungkus semua materi secara singkat agar mudah dipahami.

Tidak hanya menjadi profesionalitasnya saat di sekolah, seorang guru juga perlu menjaga sikap dan menerapkan semua bahan yang telah di pelajari. Meskipun tidak banyak guru yang menerapkan semua bagian dari yang di pelajari, namun seorang guru memiliki batasan yang perlu diperhatikan dalam menjaga sikap. Singkatnya, seorang guru juga merupakan sebuah teladan bagi semua muridnya. Maka dari itu, profesionalitas guru sangat diperhatikan sepanjang hidupnya. Maka dari itu, guru merupakan bagian dari profesi karena hanya orang yang memiliki keterampilan khusus yang dapat melakukan profesi ini. Belum lagi pendidikan dan pelatihan secara khusus yang seorang guru terima bukanlah hal yang mudah. Dan membimbing manusia bukan hal bisa di lakukan secara asal.

Guru merupakan satu di antara profesi di bidang pendidikan. Dalam UndangUndang No. 14 Tahun 2005, dikatakan guru adalah pendidik profesional dengan tugas utama mendidik, mengajar, membimbing, mengarahkan, melatih, menilai, dan mengevaluasi peserta didik pada pendidikan anak usia dini jalur pendidikan formal, pendidikan dasar, dan pendidikan menengah. Guru dapat diartikan sebagai orang yang tugasnya terkait dengan upaya mencerdaskan kehidupan bangsa dalam semua aspeknya, baik spiritual dan emosional, intelektual, fisikal, maupun aspek lainnya (Susanto, 2020: 30$31)$. 
Hak dan kewajiban guru sebagai pendidik diatur di semua peraturan perundangundangan yang berkaitan dengan pendidikan. Dalam UU No. 14 Tahun 2005 tentang guru dan dosen pada bagian kedua mengenai hak dan kewajiban pada pasal 14, adapun hak yang dimiliki oleh seorang guru sebagai berikut:

a. Memperoleh penghasilan di atas kebutuhan hidup minimum dan jaminan kesejahteraan sosial.

b. Mendapatkan promosi dan penghargaan sesuai dengan tugas dan prestasi kerja.

c. Memperoleh perlindungan dalam melaksanakan tugas dan hak atas kekayaan intelektual.

d. Memperoleh kesempatan untuk meningkatkan kompetensi.

e. Memperoleh dan memanfaatkan sarana dan prasarana pembelajaran untuk menunjang kelancaran tugas keprofesionalan.

f. Memiliki kebebasan dalam memberikan penilaian dan ikut menentukan kelulusan, penghargaan, dan atau sanksi kepada peserta didik sesuai dengan kaidah pendidikan, kode etik guru, dan peraturan perundang-undangan.

g. Memperoleh rasa aman dan jaminan keselamatan dalam melaksanakan tugas.

h. Memiliki kebebasan untuk berserikat dalam organisasi profesi.

i. Memiliki kesempatan untuk berperan dalam penentuan kebijakan pendidikan.

j. Memperoleh kesempatan untuk mengembangkan dan meningkatkan kualifikasi akademik dan kompetensi.

k. Memperoleh pelatihan dan pengembangan profesi dalam bidangnya.

Dalam melaksanakan tugas keprofesionalan dalam UU No. 14 tahun 2005 tentang guru dan dosen, pada pasal 20 maka guru berkewajiban sebagai berikut:

a. Merencanakan pembelajaran, melaksanakan proses pembelajaran yang bermutu, serta menilai dan mengevaluasi hasil pembelajaran.

b. Mengembangkan dan meningkatkan kualifikasi akademik dan kompetensi secara berkelanjutan sejalan dengan perkembangan ilmu pengetahuan, teknologi dan seni.

c. Bertindak objektif dan tidak diskriminatif atas dasar pertimbangan jenis kelamin, agama, suku, ras, dan kondisi fisik tertentu, atau latar belakang keluarga, dan status sosial ekonomi peserta didik dalam pembelajaran

d. Menjunjung tinggi peraturan perundang undangan, hukum dan kode etik guru, serta nilai nilai agama dan etika.

e. Memelihara dan memupuk persatuan dan kesatuan bangsa.

Dengan poin-poin yang telah disebutkan diatas maka alangkah lebih baiknya kita dapat menghargai guru dengan baik lagi, karna yang kita pahami bahwa banyak nya tugas 
guru yang dilakukan yang mana bukan hanya untuk mendidik tetapi juga berbagai macam hal lainnya. Pekerjaan guru dapat dipandang suatu profesi yang secara keseluruhan harus memiliki kepribadian yang baik dan mental yang tangguh, karena mereka dapat menjadi contoh bagi siswanya dan masyarakat sekitarnya. Dzakiyh drajat mengemukakan tentang kepribadian guru sebagai berikut "setiap guru hendaknya mempunyai kepribadian yang akan di contoh dan diteladani oleh anak didiknya, baik secara sengaja maupun tidak (Darajat, 2005: 10).

\section{GURU INDONESIA DAN TANTANGAN PROFESIONALISME}

Profesionalisme guru sangat diperlukan di Negara manapun. Bagaimanapun juga seorang guru merupakan suatu teladan yang akan ditiru oleh setiap muridnya. Mungkin ada beberapa guru yang melanggar profesionalisme mereka dan itu akan menjadi dampak buruk yang besar untuk sebagian murid yang di ajar.

Bagaimana bisa seseorang berperilaku buruk bisa di terima oleh lingkungan? Seorang guru mempunyai image yang sangat baik. Namun beberapa murid akan menentang sebagian tindakan yang menurut mereka tidak pantas untuk dilakukan. Kita mungkin menemukan beberapa murid yang membangkang dan sulit untuk diberitahu, namun bisa saja itu terjadi karena berasal guru tersebut itu sendiri. Bagaimana cara mengajarnya yang terlalu keras, atau mungkin mudah membandingkan seorang murid dengan yang lainnya.

Menurut Noor Jamaluddin (1978: 1) Guru adalah pendidik, yaitu orang dewasa yang bertanggung jawab memberi bimbingan atau bantuan kepada anak didik dalam perkembangan jasmani dan rohaninya agar mencapai kedewasaannya, mampu berdiri sendiri dapat melaksanakan tugasnya sebagai makhluk Allah khalifah di muka bumi, sebagai makhluk sosial dan individu yang 14 Heri Susanto sanggup berdiri sendiri. Sedangkan Rickey (1987) sebagaimana dikutif Soetjipto dan Kosasi (2009: 17) mengemukakan ciri-ciri guru sebagai profesi, yaitu:

1) Adanya komitmen dari para guru bahwa jabatan itu mengharuskan pengikutnya menjunjung tinggi martabat kemanusiaan lebih dari pada mencari keuntungan diri sendiri.

2) Suatu profesi mensyaratkan orangnya mengikuti persiapan profesional dalam jangka waktu tertentu.

3) Harus selalu menambah pengetahuan agar terus menerus berkembang dalam jabatannya.

4) Memiliki kode etik jabatan.

5) Memiliki kemampuan intelektual menjawab masalah-masalah yang dihadapi.

6) Selalu ingin belajar terus-menerus mengenai bidang keahlian yang ditekuni.

7) Menjadi anggota dari suatu organisasi profesi.

8) Jabatan itu dipandang sebagai suatu karir hidup.

Guru merupakan suatu profesi, yang berarti suatu jabatan yang memerlukan keahlian khusus sebagai guru dan tidak dapat dilakukan oleh sembarang orang diluar bidang pendidikan. Walaupun pada kenyataannya masih terdapat guru yang tidak memiliki 
latar belakang pendidikan bidang keguruan. Seorang guru berkaitan dengan aktivitas profesinya duharuskan mengetahui dan dapat menerapkan beberapa prinsip mengajar agar ia dapat melaksanakan tugasnya secara profesional, yaitu sebagai berikut.

1) Guru harus dapat membangkitkan perhatian perserta didik pada materi pelajaran yang diberikan serta dapat menggunakan berbagai media dan sumber belajar yang bervariasi.

2) Guru harus dapat membangkitkan minat peserta didik untuk aktif dalam bepikir serta mencari dan menemukan sendiri pengetahuan.

3) Guru harus dapat membuat urutan (sequence) dalam pemberian pelajaran dan penyesuaiannya dengan usia dan tahap tugas perkembangan peseta didik.

4) Guru perlu menghubungkan pelajaran yang akan diberikan dengan pengetahuan yang telah dimiliki peserta didik (kegiatan apersepsi), agar peserta didik menjadi mudah dalam memahami pelajaran yang diterimanya.

Untuk saat ini Indonesia benar-benar sangat memerlukan guru dengan profesionalitas tinggi. Karena Indonesia perlu pembimbing yang pantas untuk membangun generasi yang akan membangun Indonesia menuju sebuah Negara yang maju.

Kompetensi profesional berasal dari dua kata yaitu kompetensi dan profesional. Pengertian dasar kompetensi (competency) adalah kemampuan atau kecakapan. Dalam Kamus Besar Bahasa Indonesia kompetensi berarti kewenangan/kekuasaan untuk menentukan (memutuskan sesuatu). Keputusan Menteri Pendidikan Nasional No. 045/4/2002 menyebutkan kompetensi sebagai seperangkat tindakan cerdas dan penuh tanggungjawab dalam melaksanakan tugas-tugas sesuai dengan pekerjaan tertentu. Sedangkan profesional menunjuk pada dua hal, pertama orang yang menyandang suatu profesi, kedua penampilan seseorang dalam melakukan pekerjaan yang sesuai dengan profesinya. Jadi dari berbagai pengertian di atas maka yang dimaksud dengan kompetensi profesional guru ialah kemampuan dan kewenangan guru dalam menjalankan profesi keguruannya, artinya guru yang piawai dalam melaksanakan profesinya dapat disebut sebagai guru yang kompeten dan profesional. Kompetensi profesional merupakan pekerjaan yang hanya dapat di lakukan oleh seorang yang mempunyai kualifikasi akademik, kompetensi dan sertifikat pendidik sesuai dengan persyaratan untuk setiap jenis dan jenjang pendidikan tertentu. Kompetensi profesional merupakan kemampuan dasar yang harus dimiliki oleh guru. Ada beberapa pandangan ahli tentang kompetensi profesional guru. Menurut Cooper (1984:15) terbagi kedalam 4 komponen kompetensi dasar, yakni:

a. Mempunyai pengetahuan tentang belajar dan tingkah laku manusia

b. Mempunyai pengetahuan dan menguasai bidang studi yang dibinanya

c. Mempunyai sikap yang tepat tentang diri sendiri, sekolah, teman sejawat dan bidang studi yang dibinanya

d. Mempunyai keterampilan dalam tekhnik mengajar 


\section{SIMPULAN}

Seorang guru dapat digolongkan serta di klarifikasikan sebagai profesi sesuai karena seorang guru telah melalui hari yang panjang dengan cara mempelajari bagaimana cara mendidik dan mampu menguasai pelajaran yang akan diajarkan. Seorang guru bahkan mampu membuat sebuah silabus kegiatan Selama belajar-mengajar secara sistematis dan teratur. Mereka juga mempelajari bagaimana cara menarik perhatian para murid serta membungkus semua materi secara singkat agar mudah dipahami.

Tidak hanya menjadi profesionalitasnya saat di sekolah, seorang guru juga perlu menjaga sikap dan menerapkan semua bahan yang telah di pelajari. Meskipun tidak banyak guru yang menerapkan semua bagian dari yang di pelajari, namun seorang guru memiliki batasan yang perlu diperhatikan dalam menjaga sikap. Singkatnya, seorang guru juga merupakan sebuah teladan bagi semua muridnya. Maka dari itu, profesionalitas guru sangat diperhatikan sepanjang hidupnya. Maka dari itu, guru merupakan bagian dari profesi karena hanya orang yang memiliki keterampilan khusus yang dapat melakukan profesi ini. Belum lagi pendidikan dan pelatihan secara khusus yang seorang guru terima bukanlah hal yang mudah. Dan membimbing manusia bukan hal bisa di lakukan secara asal.

\section{REFERENSI}

Efendi, I., Prawitasari, M., \& Susanto, H. (2021). Implementasi Penilaian Pembelajaran Pada Kurikulum 2013 Mata Pelajaran Sejarah. Prabayaksa: Journal of History Education, 1(1), 21-25.

Susanto, H. (2020). Profesi Keguruan. Banjarmasin: FKIP Universitas Lambung Mangkurat.

Susanto, H., \& Akmal, H. (2018). Efektivitas Penggunaan Aplikasi Pembelajaran Berbasis Mobile Smartphone Sebagai Media Pengenalan Sejarah Lokal Masa Revolusi Fisik Di Kalimantan Selatan Pada Siswa Sekolah Menengah Atas. HISTORIA: Jurnal Program Studi Pendidikan Sejarah, 6(2), 197-206.

Susanto, H., Irmawati, I., Akmal, H., \& Abbas, E. W. (2021). Media Film Dokumenter Masuknya Islam Ke Nusantara dan Pengaruhnya Terhadap Keterampilan Berpikir Kritis Siswa. HISTORIA: Jurnal Program Studi Pendidikan Sejarah, 9(1).

Syaharuddin, S., \& Susanto, H. (2019). Sejarah Pendidikan Indonesia (Era Pra Kolonialisme Nusantara sampai Reformasi). Banjarmasin: FKIP Universitas Lambung Mangkurat. 
Nurjan, S. (2015). PROFESI KEGURUAN (Konsep dan Aplikasi).

Sidiq, U. (2018). Etika dan Profesi Keguruan. Tulungagung: Penerbit STAI [Sekolah Tinggi Agama Islam] Muhammadiyah. Tersedia secara online juga di: http://repository. Iainponorogo. Ac. Id/395/1/Etika, 20, 26. 